\title{
The Significance of “mushin”: The Essential Mind of Zen Buddhist Philosophy for Humans in a Contemporary World
}

\author{
Hisaki HASHI*
}

\begin{abstract}
In our time of an information highway, digital networks are linked around the clock. Among various data many people are unconsciously depending on IT and digital medias with their body--but without any mind. The human origin, its creative thinking and acting, transmitting one idea to another for reforming and developing something new has been quite forgotten. Against this omnipresent phenomenon the Zen Buddhist Philosophy of Mind shows a dynamic approach to re-create and re-construct a human life, accompanied by the unique concept of the absolute one, “mu” (無), mu-shin (無心), the mind of $m u$ presents a dynamic unity in its flexible activity.
\end{abstract}

Keywords: philosophy of Zen Buddhism, the essential Mind in Zen, contribution for a contemporary world

\section{Izvleček}

V današnjem času informacijske prepletenosti so digitalna omrežja povezana štiriindvajset ur na dan. Obdani z najrazličnejšimi podatki so ljudje od tehnologije in digitalnih medijev nezavedno odvisni, in sicer telesno - ne pa tudi umsko. Pozablja se osnovna dejavnost človeka, njegovo kreativno razmišljanje in delovanje, prenos idej s preoblikovanjem in razvijanjem novega. V nasprotju s to vsesplošno težavo pa zenovska budistična filozofija uma ponuja možnost dinamičnega pristopa $\mathrm{k}$ rekreiranju in rekonstrukciji človeška življenja skupaj z edinstvenim konceptom absolutnega »mu« (無), ali mu-shin (無心), kjer um muja predstavlja dinamično enost v vsej svoji prilagodljivosti.

Ključne besede: filozofija zen budizma, esencialni um v zenu, prispevek v sodobnem svetu

Hisaki HASHI, Dr. phil., durch Habilitation authorized

Professor for full areas of philosophy at the Department of Philosophy,

University of Vienna, Austria.

hisaki.hashi[at]univie.ac.at

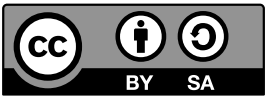




\section{What is Our Self just in Our Time of Digital Information Highway?}

In our time of digital networking, all regions of the world have been globalizing toward one direction, to get and send information as fast and as far as possible. Everything is judged as a packet of compact information, whereas the core of most of the things seems to appear just as a punctual station for sending and receiving a digital information.

These things are organized by our self, our bodily existence with consciousness. We, people of the 21st century, are accompanied by information based on cognitive scientific data, for example how our brain sees everything, how is the function of our brain activities is like, how far we can recognize our intellectual or psychic activities through a data-base, from computer tomography etc. There we are, as a system of complex functions of many sub-systems in our biological organism. We are accustomed to operate them just by natural science data base or by our objectivist thinking. We will understand everything in objectivizing digital data if we respect and value them as they become an unavoidable part of the present world.

On the other hand, the lacking part of this stream, a reversed course in thinking and acting, is less regarded: The "experiencing of everything in a full activity from the integrated oneness of body and consciousness". I. e. a fulfilled self in one's own life by every occasion, in every core of the things in the environment. The Buddhist Philosophy, especially Zen thinking is bound to this main aspect of "experiencing everything in a full activity of the integrated body and mind”.

\section{Humans as a "Splitting Animal"}

Villard van Oman Quine remarked: The thinking human, the rational thinking subject is a "split animal" in his "Kant lectures" (Quine 2003, 86-90). He shows that human beings value protocol sentences (which was presented originally by scientific positivists), for example, "Tom says: It is raining" in analytical thinking, cognitive- and natural sciences. The second half of the sentence shows an objective protocol of an occasion. The first half is bound to an empirical person within an empirical phenomenon of a circumstance, including also one's own feeling, emotions and subjectivist behavior. Quine means: A protocol sentence is in purpose of presentation of an absolute objectivity whereas it comes from the pure "subjectivity" of a human being as an individual person. The pure subjectivity of a person and his objectivist protocol sentence are always connected in a human being's personality. Even if the second half of the statement is an 
objectivist protocol sentence, it is unavoidably bound to one's subjectivist personality: Quine judges this complexity in saying that we as human beings exist as a "split animal".

Splitting into the dualistic directions - a (person as a pure subject) and a (person striving for objectivist thinking): It is evident that analytical philosophers and cognitive scientists strive primarily for the perfection of the "second half" of truth presented in a "protocol sentence". In contrast to this approach, Buddhist philosophers are mostly interested in the first half of the sentence ("Tom says", "Anne says" etc.), meaning the "pure subject", who is oriented toward grasping what the person's self is. Reflections of Buddhist Philosophy go further, whereas our own subjectivism of any kind is viewed by our own selves self-critically and cautiously. Even if we judge, we think, and we act most objectively in the Cartesian sense of rationalism, we are bounding to this fatal dualism represented by Quine- the splitting animal - into the pure subjectivity of our bodily self per se and the objectivity of our cognition.

\section{The Subject-object Dichotomy in Zen Buddhist Thinking}

Let us view how the problem (of the "split animal") is treated by the Zen Buddhist philosophy of mind. Izutsu T. represented the position of our subject-object dichotomy through a graphic as seen below (Izutsu 1977; 1986, I.4.). Our consciousness has always the structure of three stations: viewing, thinking, and acting. 1) (I see), 2) (I see myself), 3) (I see objects of mine).

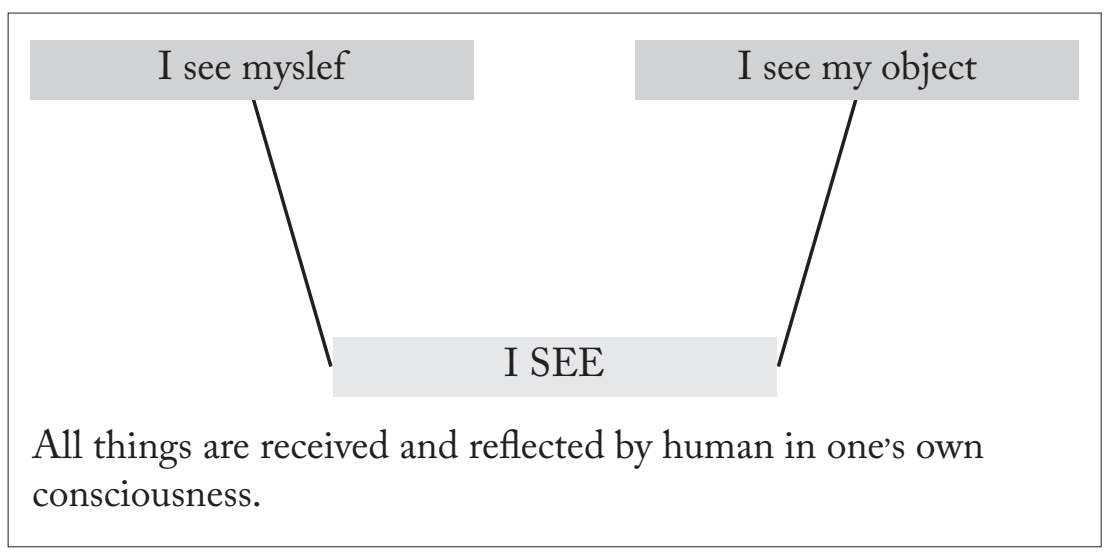

Illustration 1: The splitting subject and object (Izutsu 1986, Chap. 1.4) 
As humans in the contemporary world, we mostly have intentions regarding on the last aspect: We see the objects of ours-in daily life and also in the context of contemporary scientific knowledge. On the other hand, the reflection of one's own self, which is shown by Izutsu in the 2 nd station, is not reflected cautiously ${ }^{1}$ (Heisenberg 1991, 16).

The objectivist thinking method in Natural Science and Technology is correct just in the construct of the systematic thinking discipline. But we have to remark that this thinking method cannot be valid as an all embracing discipline. Let us see the content of our self-consciousness. Informed by experts of brain physiology and cognitive science, we can observe the routes how an electron signal runs from one part to another part of the cortex and how intensive the exchange of energy between the observed parts is. For example, when a musical sound is received by a human organism supported by neuro transmitter, we can see the route of running electrons which transmit the information (Wróbel 2011, 16-17). We can observe and protocol the whole process of how digital information is collected. But, the collected data of neuro science are not same with the human experience of "hearing a sound of music". The first one cannot replace the latter.

Recently it is often stated in neuro science that the brain function has been continuously clarified by various experiments, but that the verified and acknowledged parts are still limited and that the results of collected knowledge are depending on the following condition: "Only if the collected data has a conjunction to a 'human experience', which has been experienced in one's own life, the brain recognizes the input data in connecting to one's own experience in which a person gets one's own knowledge." For example, the present state of neuro- and cognitive science is not able to define from where and from which part of the brain's "three dimensional space" knowledge emerges. Only if a human perceives a physical thing, its horizontal and vertical dimensions, and only if the human walks to recognize how long its length is, s/he recognizes firstly what a three-dimensional thing in reality is. Also, a most highly developed state of cognitive science is not able to clarify what "consciousness" is, from where it arises, from which function of the neuro transmitter it comes from, from which collaboration of crushing parts of vertical cells one's own knowledge can be built up and so on. The data of neuroscience gets only its effective face if the human being "experiences" something and gets

1 Someone can say, that "modern physics since Heisenberg's Uncertainty Principle also remarks the relationship of observing subject and observed object, so that the reflection of our observing self is not omitted by natural scientific thinking". No. This is a very simplified modification, which is far from the origin of Heisenberg's thought. We should not forget that the full content of the Uncertainty Principle is construed through the rigorous observation and execution of the pure physicist discipline (Heisenberg 1991, Chap. I). 
"knowledge of something", whereas the neuro scientific data by itself is not able to construct and replace the same "experience of human". 2

In the Buddhist knowledge, there is a term “sangai yuishin”三界唯心, which shows a significant concept as follows: "In all areas of the three worlds (i.e. the world of greedy, the world of visible phenomena, and the world of Buddhist cognition dharma) are construed exceptionally through our mind, the mind of humans. All things are received and reflected in our mind like a mirror. If our mind is coated by our subjectivism, things are received in a subjectivist way where knowledge and thought start from this state of a biased view by one's own subjectivism ${ }^{3}$ (Hashi 2015b, 289; The Teaching of Buddha 2014, 51-60). Even if it is a highly skilled natural and cognitive scientist knowledge, viewed from the Buddhist Philosophy of mind, it is yet a special kind of "subjectivism", whereas a scientist believes in the "absolute objectivity" of natural scientist knowledge and keeps it as an absolutely centralized one. Then, during this activity to believe and keep the "most objectivist knowledge", the thinking human has executed one's own karma (not as sin!) as a "whole reality of one's thinking, acting and experiencing of life in a causal logical continuum", in one's own subjectivity, limiting the "absolute truth in an absolute objectivity". If this person is based on one's own scientific centralism, he/she reflects one's own position only affirmatively, but without setting a critical view to one's own standing point. The objective and analytic thinking person should reflect his own thinking position from a self-critical distance-as an observer to the thinking and acting unit of one's own self. Heinz von Foerster, an Austrian physicist who emigrated to the USA, positioned that he as a developed physicist looks at his own physicist position from an intellectual distanced level, "the observer of the 2nd order" (Foerster 1985a; 1985b, 81; Cf. Maturana 1985, 301). With this

2 Even if an Artificial Intelligence is highly developed and it can overcome a human ability in all areas of life, it cannot "experience" occasions of any kind spontaneously at the human level of a complexity, because it is a construed program with certain functions. Even though it can collect several types of data for itself (for example in purpose of winning the game), a further function out of the input programs could not be activated. It "learns" something, but only within the input rules including some kind of variations: Cf. Fleissner 2011, 39-58.

3 H. Maturana means in his writing collaborated with F. Varela: Even if cognitive scientists work out their objectivist analytical theory, it is unavoidable to execute one's own scientific methodology, which is limited by one's own scientific thinking subject. An absolute objectivism of cognitive scientists is bound at the same time to the execution of one's own scientific subjectivism. I, as the author of this article, will represent that the unique principle of Nishida, the so-called founder of the Kyoto School, the “absolute contradictory self-identity" (zettai mujunteki jiko döitsu 絶対矛盾 的自己同一) has here the validity to verify that an absolute objectivistic thinking of human reason is also accompanied by the pure subjectivity as limited knowledge of a human: Maturana 1982. Original positions of the problematic of "subjectivity and mind" of Buddhism are found in: Pāli Canon in Early Buddhism, in Lankā vatarā sutra (楞伽経), Huayen Sutra (華厳経) in Mahayana Buddhism: see References, category Bukkyō dendō kyōkai 2014. 
conception, Foerster got a unique position as a self-critical cognitive scientist, which was characterized in his own words as follows: "Vom Physiker zum Metaphysiker" (from the physicist to the metaphysician). Quite similar to Foerster, the Buddhist Philosophy of Mind phrases a critical and self-critical position, in which our "mind" works day by day by integrating body and consciousness, in acting and thinking accompanied by our cautious view. It is able to execute a self-corrections in relationship with the things and beings in its environment.

\section{Excursus 1:}

The characteristic of the self-positioning in this philosophy is, that the viewing nd acting Self reflects and perspectives one's own Self and in relationship to other Selves and Beings from the dimension of Experiencing in the middle of daily life. Thus, all reflections are executed from the dimension of acting self in a real time in a life world. It includes a rigorous self-critical view in self-analysis, but accompanied also by religious Compassion for suffering one: In this dimension, the Buddhist Philosophy has another starting point and another purpose, which is distinguished clearly from analytical philosophy. Problems treated in Buddhist Philosophy are overlapped sometimes with Phenomenology. But once again, it purposes the solving of suffer and self-healing in thinking and acting from the middle of the dimension of Experiencing Self (See Hashi 2015d).

Also, the calmness of Zen Practice is oriented to solve an ego-centralized mind of suffering self in a cautious insight, which clarifies the relationship of one's Self to the other beings in the environment. It has a goal in Self-Healing in relationship from one's self to another. In this positon, the deep calmness of Zen Practice is not the same of Husserl's epoché, which started from the orientation for examining and establishing the philosophy as a rigorous science.

\section{The Conflict of Our Mind}

The essential part of Zen Buddhist knowledge and cognition problematizes the "mind" of one's own subject and its fixed connection to "one's own subjectivity" per se. The self, bounding to its subjectivism in striving for an objective knowledge-by Quine the central problem of the "splitting animal"-is prepositioned in the Buddhist philosophy of mind in questioning how we can overcome this splitting and this self-contradiction through our thinking and acting in daily life (Hashi 2015b, Chap. 2.1.). Let us remember the diagram of Izutsu (Izutsu 1986, Chap. I.4). He states that our mind is construed by the integrated three principal 
positions: 1. (I see), 2. (I see myself) (and my internal world), 3. (I see my object) (primarily outside of me, in an external world): The first one, (I see), is the most fundamental principle, which is arising in the middle of an experiencing self. In other words, it is the fundamental station which enables our viewing, thinking and acting before our analyzing and psychic viewing,- "I see my objects" and "I see myself"- - are going on. Before the splitting into a dichotomy of the positions 2 (I see myself) and 3 (I see my object), the first position (I see) is input without reflection as a preposition in a non-verbal way in one's own mind.

\section{Excursus 2:}

Nishida, the founder of the Philosophy of the Kyoto School in the 20th century, characterized that Eastern Philosophy has its main aspect in viewing and reflecting on things in experiences in the middle of the world phenomena, always accompanied by the acting and thinking subject, the mind of the self. We will focus on the latter, the viewing and thinking self, which is not a briefly empirical consciousness of "I see". It is neither an Ego in the subjectivist way nor the objectivist rational thinking cogito after Descartes. The self by Nishida is, just in short, the true self in the subjectivist way that dominates and operates the others by one's own subjectivism and must be reflected and solved cautiously. The acting and thinking self is present, but the orientation and content of one's consciousness is not the same as the Cartesian "ego cogito". The self by Nishida is part of the phenomena of the whole world and universe. It is part of the environment in which self-consciousness is oriented to experience and construct a meaningful world as an egoless self (solved from the subjectivist way of thinking) step by step in daily life: Nishida called it the Logics of the essential Mind (shin no ronri 心の論理) and remarked that this main stream is quite different from that of Occidental (Western) Philosophy (Nishida 1965/66). The latter has the characteristic of objectivizing and analyzing things mostly from an observing view, a method of observing and judging every aspect in a clear-cut dichotomy of "either A or non-A". In the progressive civilization and technology of the 19th century the East Asian main stream of thinking, the subject of experiencing, viewing and knowing the self (I see) was sometimes neglected as a minority for the world's progression caused by Natural Science and Technology, case by case. Nishida emphasized that a new philosophy is expected eagerly in the middle of the progress of civilization and technology in which the objectivizing and analyzing mentality of Occidental Sciences experienced its limit. 


\section{Another Way to Solve the Conflict-In Distinguishing from Cartesian Way of Cogito}

It is obvious that the modern rational and natural scientific way of thinking has set these three stations with the highly concentrated 1st position as "I think" (je pense, ego cogito). In the rational scientific thinking of Descartes, which was shown clearly in the Discourse de la Méthode, chapter 5: It corresponds the 3rd position of the diagram of Izutsu (I see my object) which is highly closed up in the frame of "observing an object to find a certain rule of the nature of physiology and medicine"The essence of Descartes' thinking was actually noticeable in the fourth chapter, in which almost all reflections for things which are "right, clearly logical, and sure" in every repetition of examinations when one's own recognition for oneself goes on from "I think" and verifies it as a "concrete existence of rationality as a sub-system attached to the highest creator God" in an open mind (which sounds quite optimistic). (Descartes 2009, 71-77) Here we can see that the same construction for trusting human's own rationality as the highest project attached to God can be hardly found by Buddhist Philosophy, since the latter has not set a highest creator in a personalized form. The characteristic of Buddhist dharma (the entity of orders, systems, and networks of truth of various kinds) is independent on brahman as a principle of moving and creating all things of the world like God does as a creator. A theistic character was solved in Early Buddhism by Buddha and in the lanka vātara sütra in Mahayana Buddhism, the monotheist theory is definitively distinguished from Buddhist original positions (Nakamura 2003a). Especially in Zen Buddhism the creator of the world (God) was out of any questions. The most important thing to achieve is the discovering of a pure humanity in one's own bodily existence, in Buddhist term "the Buddha Nature" (busshō 仏 性) (Nakamura 2003b; Hashi 2014a). A kind of credo in Zen Buddhist way of thinking is characterized by the integration of three principles:

1) Believe firmly the potential to state one's own Buddha Nature in our bodily existence (大信根 dai-shinkon),

2) Keep a doubt for a limited ability of one's acting and thinking to grasp and state one's Buddha nature大疑団 dai-gidan) and

3) Strive actively and affirmatively toward achieving the true Buddha Nature in ourselves (大奮志 dai-funshi) (Hashi 2014a, III, Chap. 3: 181-83)

From this view, the diagram of Izutsu shows a most interesting aspect. Regarding Buddhist philosophy, we see a famous aspect: Everything in the world is bound to the way of a subject's mind: If the subjective mind tend to see and value everything in a negative way, the whole world in its environment metamorphoses in a negative and pessimistic way. If the mind has been changing itself, the world's 
environment arises into a positive and clear view. The world is always a limited world which remains in a frame of one's own self-consciousness and which is always changing in a network of relations between the environment and the human.

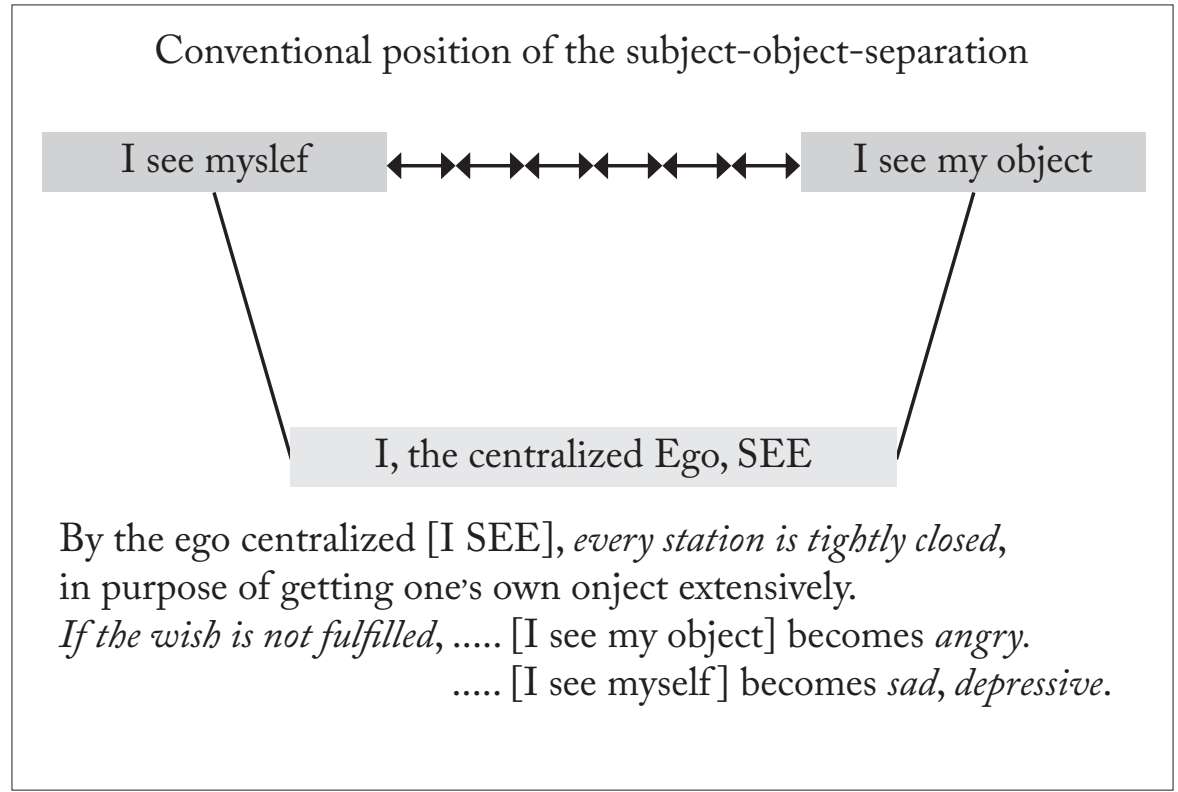

Illustration 2: Closed dimension in one's own ego-centralized mind

Separated from the Cartesian high level of rationalism, most humans exist without cautious reflection to this construction of dichotomy. We are bounding to this triadic which is often tight and firmly closed, whereby our Ego [I SEE] unconsciously centralizes and expands dominantly ${ }^{4}$ (Hashi 2014a, II, Chap. 7).

\section{The Absolute Truth as an Unlimited Oneness-the “ $m u$ " in Zen Buddhist Thinking}

The Absolute One in Zen Buddhist Thinking is, in brief, neither "God" nor "Nothingness" as framed in Occidental philosophy. It is an unlimited oneness, which is not identified with the one. Therefore in Zen thinking it is called "Oneness without One" (一無一) (Ueda 1986). The negated word, the first "one" and the last "one", are just the same in the original Chinese script. But their meanings are different.

4 For the conception of the "Mind" and "Mindfulness" of Classic Zen literature see also Hashi 2014a, Appendix to Main Section II, "Bodhidharma: Über den Geist". 
The first "one" is the fundamental, absolute, all enveloping Oneness which is not a creator like God in Occidental religions. The last "one" is a unit or one in an empirical phenomenon in a life world.

Whereas Zen Buddhism has been developing from the beginning without bounding to an existence of God, the focus of Zen thought is concentrated to the living world, the self as an integrative unity of body and mind. The latter is a creative dimension of bodily existence and consciousness. It is not only a point of receiving, copying, and delivering various information. Furthermore, it is a creative dimension for actualizing truth. Terminologically I call it the "corpus" (Hashi 2014a, I), which did not receive the same meaning as in the French phenomenologists. One of the characteristics of my terminology is that this "corpus" works as an awakening self (Akizuki 1978) in striving for realizing an unlimited truth day by day in a co-existential network for one's own self and the others. Its goal is quite idealistic to "realize and actualize an eternal good and truth" (like the idea of Plato). At the same time, it is different from the characteristic from Plato, which says that this goal should be realized in an empirical life world or in a middle of world immanence. The ideal must be actualized in reality. If not, it collapses into a "well drawn rice cake in a picture cannot satisfy a hungry person” (Dōgen 1980; 1993) (gabyō fu-jūki 画餅不充飢). The cautious mindfulness in Zen Buddhist thinking is always bound to the reality of a real world and real life. It does not contain a separation of the real experience in a living world from a world of pure idea in any kind. The mind (心) is, in another word, a highly integrated and self-critical unity which is able to integrate everything that is in a position of contradiction. It is an integrated unity of the both contradictory poles, for example the subjectivity and objectivity, the relation of one's own self and another self, an emotionality and rationality etc. Let us remember the note number 6, the special term of Nishida (Kyoto School), the "absolute contradictory self-identity" (zettai mujunteki jiko doitsu 絶対矛盾的自己同一).

In order to find out why our mind is able to integrate a contradiction, the Zen Buddhist philosophy does not ask for the existence of an absolute creator (God) in a personalized form. In Buddhist philosophy the world neither has a fix beginning nor ending. There is no substance in a thing which is able to remain forever. Things are in a dynamic change, accompanied by the time which is emerging, staying and vanishing in every moment. The causality of that why Buddhist Philosophy emphasizes terms in negative expressions, for example an-ätman (non-self, non-ego), anitya (non-stability, non-substantiality), etc., shown in this kind of realistic view. There is no being of an absolute God, no stability of things forever: the being one always accompanies its moment to fall into nothingness, since every moment is bound to a factum of that one moment in a time that emerges, stays shortly, and 
vanishes, whereas another moment arises, stays shortly and also vanishes. Being in a space is bound to this rule of time (emerging-staying-vanishing), in which nothing remains forever in an absolutely identical condition (Nakamura 2003, vol. 5; Hashi 2014b; Hashi 2015a). As the world's phenomena are not bound to an absolute creator, the mindfulness in Zen Buddhist philosophy is getting to the centre of every problem in order to clarify and establish what we are, what our self is, and how to deal with every problem in daily life. A typical form of Zen Buddhist cognition is grasping that there is no fix substantiality of our self, which is found in various relations in networks between one's self and the other. Everything is in a dynamic change, whereas our self-consciousness tries to define and to represent what our self is able to do in its best way. But this self has a fundamental contradiction in it: i.e. in the 1st Station of (I see) it is a pure subject in breathing, thinking, viewing, and doing. On the other hand it tries to grasp itself as an objective mind, attempting to realize how we are positioning ourselves in an environment and in our relation between us and every circumstance. The Zen Philosophy tries to fill this gap, namely a pure subjectivity of our self and its intensive expect for objectivizing, with the fundamental method of " $m u$ ", the method of an absolute negation to build up a fixed idea or dogmatic concept (I see), whereas we are a unity of self-contradiction that finds itself staying and vanishing in every relation in a real life. (I see myself) is also accompanied by this contradiction that we can objectify the things only in a frame of our born, inherent subjectivity. (I see the object) is also accompanied by a rigorous self-critical mind-that we will grasp objects mostly in a frame of our subjectivist self-centralized mentality and try to establish them in a scientist category of an "absolute objectivity" from a scientist position as a "upervisor" (Cf. Descartes 2009). Herein the Zen Buddhist philosophy, based on the principle of " $m u$ " (literally translated as "nothingness") has the goal for "negation and solution of a subjective mind in any kind" which results in an "open court of ourself in a cautious view of mindfulness" (See the next chapter to find out what this means in detail!).

\section{The Absolute Liberty in the Mindfulness of Zen Buddhist Philosophy}

Let us view the diagram based on Izutsu, in which a self-rigorous criticism and negation is shown in a dynamic solution based on the graphic I have mentioned previously. I interpret this dimension of the three stations of Viewing, Thinking, and Acting of humans as a creative corpus for solving of every dogmatic fixation to a conventional thinking. The latter is, for example, how Dōgen, one of the leading thinkers and monks of Japanese Zen Buddhism, presented his position as follows: "Usually we say that 'we see the mountain' as our object. We, as a thinking subject 
see the object, whereas the mountain cannot see us as an inorganic entity." (Dōgen 2004, II; 1993) Dōgen said that it is a typical conventional way of thinking to centralize ourselves and pretend that all other things in our environment are only bound to our thinking ego, so that things among us could be/should be dominated and operated by the knowledge of human. Dōgen expresses the opposite position clearly: "NO" (Dōgen 2004, II; 1993). It is not just that we see the mountain and other things in environment as nothing more than objects which must be operated by human. Before we put our knowledge or our rationality into the scheme "we see the mountain", the mountain shows us presently what it is as it is. Only if the mountain shows itself, we can view it clearly_ "What It is-As It is"-without putting on our subjectivism of any kind. Herein, the mountain and we humans co-exist in an intra-relation. The mountain (the part of the whole nature) and we (the part of humankind) are in a relationship of mutual transmission. Herewith, the exchange of subject-object positioning is possible in Dōgen's Zen Buddhist Philosophy: We can also say that "we see the mountain" and at the same time that:

The mountain sees us; The mountain goes with us;

The mountain flows with us in the eternal stream of time.

(Dōgen 2004, II; 1993)

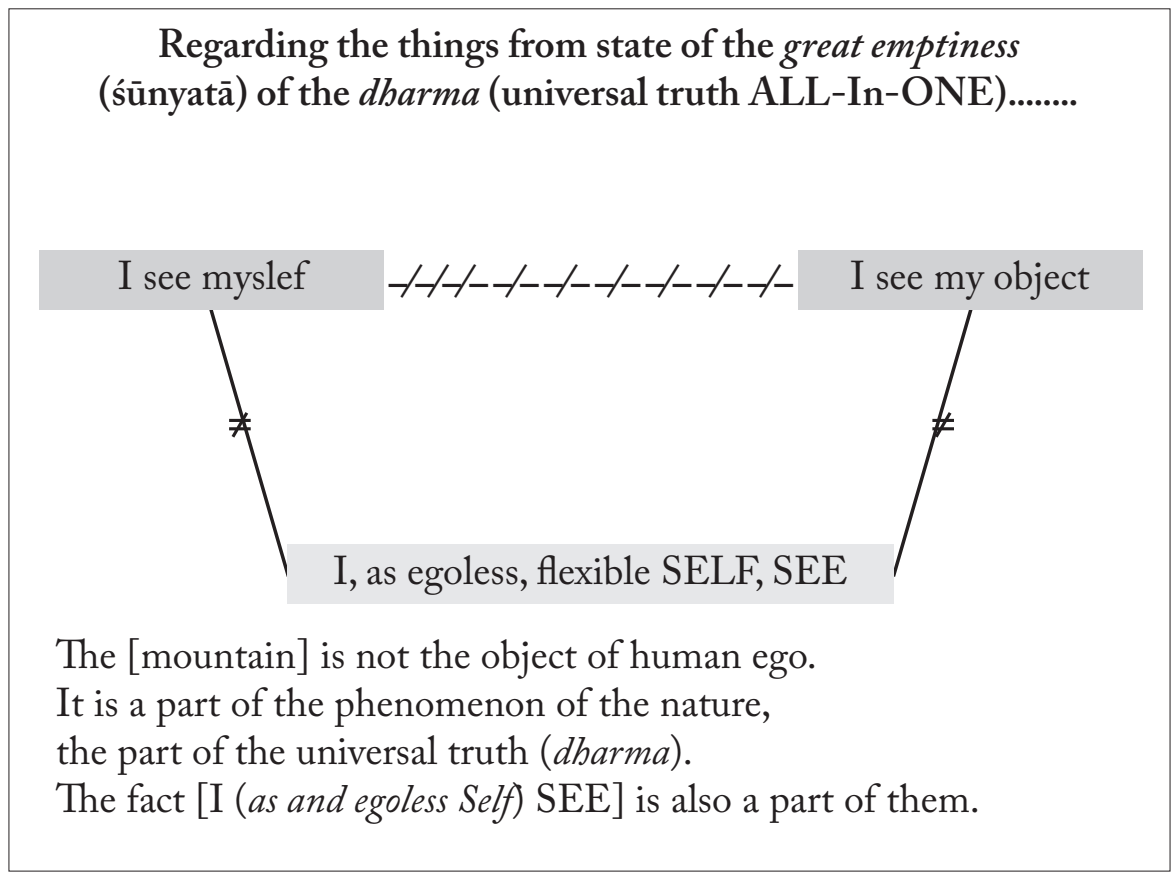

Illustration 3: Liberation of one's own Ego-Centralism (cf. Hashi 2009) 
This kind of dynamic flexibility to solve our subjectivism and to remind the mutual transmission between human and nature results directly of what is known as the mushin (無心), the pure mind of mu as an open court for viewing, reflecting everything clearly without being bound to one's subjectivism, in acting and realizing a truth based on the corpus - one's bodily existence - to acting and expressing a part of an eternal truth in daily life. In other words, this corpus performs a full mindfulness in cautious view and the dynamic liberty. This perspective can be shown in the basic diagram of Izutsu, which I would modify as follows (Cf. Izutsu 1986, I: 4): ${ }^{5}$

Every station of self-consciousness reflects cautiously every route in the triad. It keeps itself as a human origin, but it negates tentatively every unnatural fixation like a dogma which tights one's station to another, so that a closing dimension of a subjectivist ego-centralized self should be solved by achieving an original liberty of pure humanity: Buddha Nature. It is never the same with nihilism of any kind. The absolute negation of the fixated mind between us and things in the world brings us to an absolute liberty (freedom) of our breathing self as a bodily corpus that is open to every relation between our self and things in the environment, i.e. without any disturbance and that is also free for constructing a fresh, affirmative, and creative relation between one's bodily self and others.

Subject-Object-circulation, unification, relationship in the Philosophy of Zen Buddhism

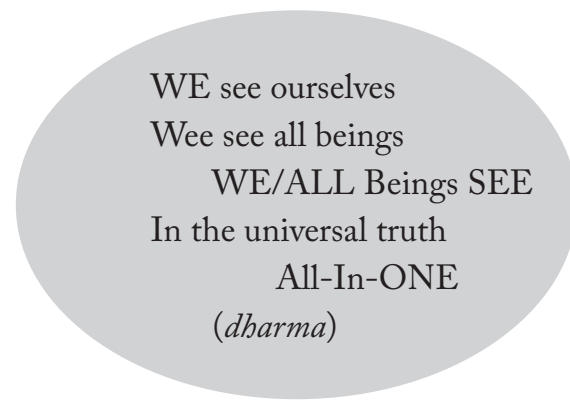

Every subject (individual, particular one), is regarded from the viewpoint of others, an object. Every object is, regarded from another viewpoint, a subject.

Illustration 4: Subject-Object-Circulation, Unification and Relationship

5 The basic structure of the diagram is based on Izutsu, is cleared up by Hashi to present exactly what is the self-liberation (gedatsu 解脱) and self-transcendence (in sense of Dōgen, tōdatsu 透脱) in Zen Buddhist Philosophy. 
Our full body and mind are completely in the oneness dimension, fulfilled by positive energy, but without any fixation of egoism. This circumstance is called the "mushin" by Zen Buddhism, the mind which is never fixated to any subjectivist position. This point shows the "fulfilled mindfulness of $m u$ as an unlimited dimension in striving for truth". The Self bears this open mind is called the " $m u$-self", muga (無我) in Zen Buddhism, which is often called as “non-self”. I will translate it in another way in view of semiotic relevance: an "unlimited self in an egoless open mind (in solving of any subjectivist limitation and ego-centralized view)" (Dōgen 2004, II; 1993; Cf. Hashi 2015c). ${ }^{6}$

\section{Conclusion}

It is necessary to summarize that the "mushin", the unlimited self-consciousness in an egoless open mind, is based on a dynamic self-negation and self-reconstruction in our daily life, so that it is not a static situation without any motion (contrary to the "apathie" of stoa). It is a clear awareness of self-consciousness within the integration of body and mind, by which the thinking and acting self solves one's own subjectivism carefully. The theoretical side of the "mushin" is explained in this article, but principally, it should be practiced in one's own life and in one's intellectual and empirical activities. Trial and error comes again and again. The act of solving one's own subjectivism in getting a transparent insight into the environment in daily life can be performed continuously.

We, the humans in our century, are fully occupied with an array of information, with pressure to do everything immediately, with being bound to a deadline of several schedules. In my opinion this system brings humans gradually to a burnout syndrome. The "freedom" of one's self is totally exchanged randomly, for example with an uncontrolled arbitrariness of ego. The important aspect of the "mindfulness" of the mu-shin (無心) (Suzuki 1989, Chap. 4), the fulfilled mindfulness without bounding to egoism, is that our self is in an invisible network of relations between our self and other selves, things and beings in an environment. We are a part of this invisible network in which our self cannot be bound to any fixed

6 Hisamatsu, Shin'ichi (1889-1980), one of the leading philosophers of the Kyoto School, the expert of Zen Buddhist Philosophy, named it the "Formless Self" in the meaning of an egoless Self in an enormous flexibility to reconstruct one's own self in relationship with other selves in their circumstance and environment. It is idealistic of the self, transcending in a clear awareness in a worldly immanence. Hisamatsu accented the "Ego transcending Self" (超個) in an idealist way. Akizuki Ryomin (1921-1997), a disciple of Zen thinker Suzuki Daisetz, accented the relationship of the "Idealist Self Transcending" and the "Empirical Self in a Life World" and calls it the "The empirical Self accompanied by Self Transcending” (超個の個) (Hashi in print). 
ideology or fixated mind of any kind. Absolvere, the Latin verb for "solve" and solution, shows an open time-space in which every point of subjectivist fixation is solved perfectly. The self is positioned in a dynamic possibility in its autonomy. According to the things in environment our self can construe the best relation between our bodily existence, things and beings as co-existential partners. I think this "fulfilled open mindfulness" is able to contribute a relevant concept for the humans in our time as an integrative unity of body and mind, which is the best medicine for self-healing against a hectic inhuman survival game.

\section{References}

Akizuki, Ryōmin. 1978. Chosaku-shū (Collected Works), vols. 7, 8. Tokyo: Sanichi shobō.

Bukkyō dendō kyōkai (Society for the promotion of Buddhism), ed. 2014. The Teaching of Buddha. Tokyo: Bukkyō dendō kyōkai.

Descartes, René. 2009. Discourse de la Méthode pour bien conduitre la raison et chercher la verité dans les sciences, edited by H. Ostwald. Stuttgart: Reclam.

Dōgen, Kigen. 1980. Shōbō genzō, vols. 1-2, edited by Yaoko Mizuno and Tōru Terada. Tokyo: Iwanami.

—. 1993. Gendaiyaku shōbō genzō, edited by Sōichi Nakamura and Sōjun Nakamura. Zen bunka gakuin (Institute of Zen Culture) in Nagoya, Tokyo: Seishin shobō.

—. 2004. Shōbō genzō, vol. 1-8, edited by Fumio Masutani. Tokyo: Kōdansha. Fleissner, Peter. 2011. "Mathematical Modelling and Computer Simulation:

Pathways to Truth?" In What is Truth? In Philosophy and in Different Scientific Disciplines, edited by Hisaki Hashi and Jóyef Niżnik, 39-58. Vienna: Polish Academy of Sciences.

Foerster, Heinz von. 1985a. "Entdecken oder Erfinden. Entdecken oder Erfinden: Wie läßt sich Verstehen verstehen?” In Einfübrung in den Konstruktivismus, edited by Heinz Gumin and Armin Mohler, 27-68. München: Oldenburg.

—. 1985b. Sicht und Einsicht. Braunschweig: Friedrich Vieweg und Sohn, Braunschweig.

Hashi, Hisaki. 2014a. Philosophische Anthropologie zur globalen Welt. LIT: Münster, Berlin, Zürich, London and Wien.

—. 2009. Zen Und Philosophie: Philosophische Anthropologie Im Zeitalter der Globalisierung. Wien: Edition Doppelpunkt.

—. 2014b. "Cognition Embodied in Buddhist Philosophy." Philosophy Study 4 (2): 136-41. 
—. 2015a. "Phenomenon of Life and Death by Dōgen and HeideggerIn View of 'Embodied Cognition' in Buddhist Philosophy and Phenomenology." Asian Studies 3 (1): 105-28.

—. 2015b. "Zur Bedeutung der 'Willensfreiheit' - An den Grenzen der Cognitive Science und Philosophie." In Denkdisziplinen von Ost und West, edited by Hisaki Hashi, 284-307. Nordhausen: Traugott Bautz.

- 2015c. "The Theory of 'Between' - 'Transmission' - 'Intra-Relation'. Toward the Cognition of the Universal Truth in Huayen - and Zen Buddhism." In Buddhism - Science and Medicine, edited by Friedrich G. Wallner and Gerhard Klünger, 79-94. Nordhausen: Traugott Bautz.

—. 2015d. "Phenomenology and Buddhist Philosophy." Dialogue and Universalism 3: 179-98.

- In Print. "Execution of the Post-Modernism in Zen Philosophy of Hisamatsu - In Realization of the Ideal of 'FAS'.” Ljubljana: University of Ljubljana.

Hisamarsu, Shin'ichi. 1971/1972. Chosaku-shū (Collected Works), vols. 1, 2. Tokyo: Risō-sha.

Hisamatsu, Shin'ichi, and Keiji Nishitani, eds. 1977. Zen no bonshitsu to ningen no shinri (禅の本質と人間の真理). Tokyo: Sōbun-sha.

Izutsu, Toshihiko. 1977. Toward the Philosophy of Zen Buddhism. Teheran: Iranian Academy of Philosophy.

—. 1986. Philosophie des Zen-Buddhismus. Hamburg: Rowohlt.

Maturana, Humberto. 1982. Erkennen: Die Organisation und Verkörperung von Wirklichkeit. Braunschweig: Vieweg.

Nishida, Kitarō. 1965/66. “Nibon bubka no mondai 日本文化の問題.”In Complete Works, vol. 12. Tokyo: Iwanami.

Nakamura, Hajime, ed. 2003a. “Ryōga-kyō 楞伽経Lankā vataraā sutra.” In Daijō butten, vol. 5. Tokyo: Tokyo shoseki.

—. 2003b. “Kegon-kyō 華厳経 Huayen-Sutra.” In Daijö butten, vol. 5. Tokyo: Tokyo shoseki.

Quine,Willard Van Oman. 2003. Wissenschaft und Empfindung. Die Immanuel Kant Lectures (problemata) "Endolegomena", translated by Howard G. Callaway. Stuttgart-Bad Cannstatt: Frommann-Holzboog.

Suzuki, Daisetz. 1989. Zen Buddhism and its Influence on Japanese Culture, Japanese translation by Momoo Kitagawa (Zen to nihon bunka). Tokyo: Iwanami.

Ueda, Shizuteru, ed. 1981. Zen no sekai 禅の世界. Tokyo: Risō-sha. Wróbel, Andrzej. 2011. "What does the Brain see?" In What is Truth? In Philosophy and in Different Scientific Disciplines, edited by Hisaki Hashi and Józef Niżnik, 11-20. Vienna: Polish Academy of Sciences. 